\title{
単一光子伝送による高速量子暗号通信システム
}

\author{
富田 章久 ${ }^{1}$, 田島 章雄 ${ }^{2}$

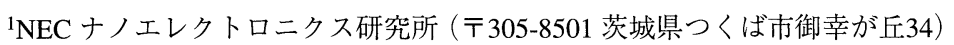 \\ ${ }^{2} \mathrm{NEC}$ システムプラットフォーム研究所（２11-8666 神奈川県川崎市中原区下沼部1753番地）
}

\section{Fast Quantum Cryptography System Using Single Photon Communication}

\author{
Akihisa TOMITA $^{1}$ and Akio TAJIMA ${ }^{2}$ \\ ${ }^{1}$ Nano Electronics Research Laboratories, NEC Corporation, 34 Miyukigaoka, Tsukuba, Ibaraki 305-8501 \\ ${ }^{2}$ System Platforms Research Laboratories, NEC Corporation, \\ 1753 Shimonumabe, Nakahara-ku, Kawasaki, Kanagawa 211-8666
}

(Received March 24, 2008)

\begin{abstract}
Quantum Key Distribution (QKD) systems based on single photon transmission can generate unconditionally secure common key between remote users. Improvement of QKD performance, particularly on key generation rate, has been required to meet current network traffic. High key generation rate is realized by increasing photon detection rate and by reducing error rate. Therefore, a high-speed QKD system should be equipped with low loss receivers with high visibility, highly efficient photon detectors with small dark count probability, and a stable clock synchronization system with low stray light to the quantum signals. A solution for these issues are given by employing planar lightwave circuit interferometers, single photon detection circuits and modules, and clock synchronization based on Wavelength Division Multiplexing (WDM) technique.
\end{abstract}

Key Words: Quantum, Cryptography, Single, Photon, Communication

1.はじめに

インターネットをはじめとする情報通信技術の普及に よってますます多くの情報が電子的に伝送されるように なっている。この中には，外交・防衛など国家の安全に 関わる情報や巨額の資金が関わる経済活動の情報など重 要度の高いものが含まれる。これらの情報を守るため, 安全性が証明可能で将来も陳腐化しない暗号法の実現が 望まれている。従来から最高度に機密性の高い情報はワ ンタイムパッドといわれる方法で送られてきた。しか し，この方法は暗号化にメッセージと同じ長さの暗号鍵 を必要とし，しかも暗号鍵は1度しか使えないため，暗号 鍵の補充が問題になる。量子暗号鍵配送 $(\mathrm{QKD})$ は通信回 線によって安全な暗号鍵を共有するための技術の一つで ある。 QKDは他の方式と異なって, 物理的に妥当な少数 の仮定を満たせば情報理論的に安全な鍵共有ができ，さ らに安全性の根拠が物理法則にあるため, 盗聴技術の進 歩による安全性の低下がないことが特徴である，QKDの 実現に向けた研究が盛んに行われ，既に原理実証を過ぎ て実用性検証に入っている。しかし，伝送可能距離や暗 号鍵の生成速度の点で未だ性能の改善が必要であると考 えられている，QKDの原理や基本的なプロトコルについ てはレビュー1)や解説記事2,3)があるため，本稿では高速化
技術を詳しく述べることにしたい。

鍵共有に要求される速度はアプリケーションによって

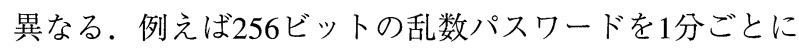
更新するといった用途では4.27 bpsで鍵生成ができればよ い. 一方，10 Gbpsのビットストリームを丸ごとワンタイ ムパッドで暗号化しようとすればそれだけの鍵生成速度 が必要である。しかし，常識的には機密性の高い情報は それほど大量でない。一時的に大量の伝送が必要な場合 には事前に暗号鍵を貯めておくことでも対応できる。こ こでは一応の目安として $128 \mathrm{kbps}$ 程度を考える．波長多重 を用いれば圧縮された動画に対応する $1 \mathrm{Mbps}$ 程度への拡 張は容易である。また，1時間鍵生成を行えば58 MBの データを暗号化できる。

高速化といっても，QKDでは鍵の安全性が保たれなく てはならない. QKDの安全性の根拠は，1光子を状態に関 する事前の知識なしに測定(盗聴)すると，必然的に誤りが 生じることにある，逆に，誤り率から盗聴された情報量 を推定して，安全な鍵を蒸留することができる。つま り，QKDを行うためには1光子が干渉性を保ったまま伝送 される量子通信と, 誤り訂正・秘匿性増強2)といったデジ タル処理の 2 種類のプロセスが必要である. パイプライン 処理ができるので鍵生成に要する時間はどちらか長い方 で制限される。現状では量子通信が律速しているが，今 
後の伝送技術の進歩で量子通信の時間が短くなるとデジ タル処理の高速化も必要になる。本稿では高速化の話題 のうち，BB84プロトコルを実装したファイバ系システム に関し，我々の研究成果を中心に鍵伝送の高速化技術を 解説する。高速化への試みとしては他にDPS ${ }^{4}$ (Differential Phase Shift)などの新しいQKDプロトコルが検討されてい る.DPSを用いるとBB84プロトコルに比べ同クロック周 波数での伝送レートが2倍になる。ただし，BB84プロトコ ルは実用的なシステムで盗聴者の能力に制限をおかずに 情報理論的な安全性が証明されている今のところ唯一の プロトコルであるため, 安全性を重視する立場ではBB84 プロトコルを選択することになる。

伝送速度を上げるにはクロック周波数を上げることが考 えられるが, 現状では光子検出器のデッドタイムで制限さ れている。広く用いられているInGaAsアバランシェフォト ダイオード $(\mathrm{APD})$ 光子検出器では光子検出後約 $1 \mu \mathrm{s}$ 程度 は, アフターパルスという現象のため誤検出確率が大き く, 次の光子を受信できない. このため, 光子検出器の低 アフターパルス化が必要である.Si-APDはInGaAs-APDよ りもアフターパルスが小さい. また, 超伝導光子検出器5) (SSPD)にはアフターパルスが殆どなく, 高速性に優れて いる. InGaAs-APDに関しても光子検出回路の工夫によっ て光子検出を高速化する試みがなされている6,7). Si-APD 光子検出器を用いた実験としては, $800 \mathrm{~nm}$ 帯の光による $1.25 \mathrm{Gbps}$ の空間伝送 $\mathrm{QKD}^{8)}, 1.55 \mu \mathrm{m}$ 光を波長変換検出し た $1 \mathrm{GHz}$ クックDPS-QKD ${ }^{9)}$ が報告されている。ささに， SSPDを用いた10 GHzクロックによるDPS-QKD ${ }^{10)} も$ 実験さ れている。しかし, 量子通信の場合, 時間同期の安定性 や，信号処理の速度を考慮するとシステムのクロック周 波数は通常の光通信よりも低く抑える必要がある. 現状 では1-2 GHz程度以下が実用的であると考えられる。

高速化に有効な方策としてはこの他に, 光子検出率の 改善や伝送された鍵から安全な鍵を生成する効率である 鍵生成率の改善も重要である。量子通信では, 伝送路で の損失や検出器の効率のために送信された光子の大半が 失われ，たまたま検出された光子で暗号鍵の共有を行っ ているため, パルスあたりの光子検出率の向上で鍵の伝 送レートは増大する。

現在行われているデコイ法によるBB84の実装では平均 光子数 $0, \mu_{1}<\mu_{2}<\ldots<\mu_{n}$ の弱いコヒーレント光パルスを 送信し, 受信者が検出したパルスのうち送受信基底が一 致するものを残し(基底照合), さらに最大平均光子数 $\mu_{n}$ のパルスのデータから暗号鍵を生成する ${ }^{3)}$. 送信されるパ ルスのうち $\mu_{n}$ のパルスの割合を $\kappa_{n}$ とすると, 鍵生成に使 われるパルスが得られる確率は1パルスあたり

$$
\begin{aligned}
P_{\text {sift }}= & \frac{1}{2} \kappa_{n}\left[1-\exp \left(-\mu_{n} 10^{-(a l+\beta+\gamma) / 10} \eta\right)\right. \\
& \left.+1-\left(1-10^{-\beta / 10} \eta\right)^{N_{e x t}}+P_{d}\right] \\
\approx & \frac{1}{2} \kappa_{n}\left[\mu_{n} 10^{-(a l+\beta+\gamma) / 10} \eta+N_{e x t} 10^{-\beta / 10} \eta+P_{d}\right]
\end{aligned}
$$

で与えられる。係数 $(1 / 2)$ は基底照合によるものである. ここで, $\alpha[\mathrm{dB} / \mathrm{km}]$ は距離 $l[\mathrm{~km}]$ の伝送路の損失係数, $\beta$ $[\mathrm{dB}]$ は受信器の損失, $\gamma[\mathrm{dB}]$ は伝送路での距離に依存しな
い損失を表す。第1項は平均光子数 $\mu_{n}$ のコヒーレント光 (信号光)が損失のある伝送路を通った後, 効率 $\eta$ の光子検 出器で光子が検出される確率である. 第2項は外部からパ ルスあたり $N_{e x t}$ 個の光子(ストレー光)が信号光に混じって 受信器に入射して検出される確率, 第3項は光子検出器の ダークカウントの寄与を表している. 具体的な数值とし $\tau, \alpha=0.2 \mathrm{~dB} / \mathrm{km}, \beta=5 \mathrm{~dB}, \gamma=0, \quad l=50 \mathrm{~km}, \quad \eta=0.1$, $\mu_{n}=0.4$ とすると信号光が検出される確率は $1.3 \times 10^{-3}$ であ り, ほぼ1000回に1回しか検出されないことになる. 光子 検出率を上げるには受信器の損失 $\beta$ を低減し, 光子検出器 の効率 $\eta$ を向上させることが必要である. もちろん, 単一 光子光源ができれば $\kappa_{n}=1, \mu_{n}=1$ としたことになるので 光子検出率の向上が期待できるが，クロックごとに必ず1 個光子が伝送路に送られる理想的な状況が実現できるため には相当の研究開発が必要となる. 今のところデコイ法に よる方が高い光子検出率が得られ, 現実的である.

鍵の生成レートを上げるための鍵生成率の改善の方策 は誤り率を低減することである。誤り訂正で失われる ビット数が減るだけでなく, 秘匿性増強のために捨てる ビットを少なくできるからである。これは，量子暗号で は誤りは盗聴行為に起因するとみなすため, 誤りが多い とそれだけ盗聴者が乱数に関して情報を得たと考えるた めである．上のモデル (1)での誤り率 (QBER) は以下のよ うに与えられる：

$$
Q B E R=\frac{\frac{1}{2}(1-v) \mu_{n} 10^{-(a l+\beta+\gamma) / 10} \eta+\frac{1}{2} N_{e x t} 10^{-\beta / 10} \eta+\frac{1}{2} P_{d}}{\mu_{n} 10^{-(a l+\beta+\gamma) / 10} \eta+N_{e x t} 10^{-\beta / 10} \eta+P_{d}}
$$

ここで,vは受信器 (干渉計)の明瞭度である.上の式か ら, 誤り率を小さくするには明瞭度を高め, ストレー光 を低減し, ダークカウント確率を小さくすればよいこと が分かる。

まとめるとQKDの高速化のためには，(1) 損失が小さ く, 干渉の明瞭度が高い受信器, (2) ダークカウント確率 が小さく, 光子検出効率の高い光子検出器が望まれる. さらに光子検出器は高いクロック周波数にも対応できる ことが必要である。また，(3) ストレー光の大きな要因は 量子レベルの信号光と同時に送信される古典的強度の同 期信号光であり，この漏れこみの低減も課題となる. 我々はこれらの問題を(i)PLC (Planar Lightwave Circuit)を 用いた干渉計，(ii) APD用の信号検出回路の開発とモ ジュール化，(iii)WDMクロック同期技術の開発によって 解決した。 以下ではそれらの技術の詳細を述べる。

\section{PLCを用いた干渉計}

\section{1 一方向型量子暗号技術}

長時間安定動作が多数報告されてきた往復型方式11)に よる量子暗号技術は, その光学系構成に起因する速度の 制限があった。一方, 一方向型方式は, 干渉計の送受信 者で独立に非対称干涉計を持つ必要があり両者の遅延量 同期制御が必須となるものの, QKDの長距離・高速化を 達成できる. 特に, PLCを用いた干渉計は, 光ファイバに よって構成される干渉計に対して, 精度良く同一の光回 
路を量産可能で, 温調のみにより安定な動作を実現可能 という特徵を有している12).

一方向型方式においてBB84を実装する際の2つの有力な 方法として，4值位相 $(X Y$ 基底) コーディング(以下，方式 A) と，2值位相 + 時間 $(\mathrm{XZ}$ or YZ) コーディング (方式B) が報告されている。後者は受信側に変調器が不要となる 為，その損失分だけ伝送速度の高速化が図れる。前者で も受信信号をビームスプリッタによりそれぞれ位相差の 異なる干渉計へ入力することにより変調器を不要とする ことも可能だが，過剩損失があることや制御対象である 干渉計が増えるという問題がある. 上記AB両方式に対応 できる汎用性の高い量子暗号送信器は $2 \times 2$ 干渉計と 2 電極 MZ変調器を使用することで実現することができる13).

\section{2 量子暗号送信器構成}

Fig. 1 に $2 \times 2$ 干渉計と 2 電極MZ変調器を使用した量子 暗号送信器構成を示す。LDによって生成した光パルス を，2×2干渉計を通すことで 2 連パルスへと時間分離す る. 2 電極MZ変調器を使用して，この 2 連パルスの相対 位相及び相対強度を変調する．2電極MZ变調器の入出力 はMZ各経路における位相シフト $\phi_{1}$ 及び $\phi_{2}$ を用いて次式 で表すことができる。

$$
E_{\text {out }}=E_{\text {in }} \cos \left(\left(\phi_{1}-\phi_{2}\right) / 2\right) \cdot \exp \left(i\left(\phi_{1}+\phi_{2}\right) / 2\right)
$$

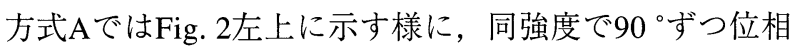
の異なる4状態が必要となる。 MZ変調器の片経路を 0 ○と $180^{\circ}$ の変調位相で, 他方を $90^{\circ}$ と $270^{\circ}$ の変調位相で駆動 することで, 式(3)の強度項である $\cos \left(\left(\phi_{1}-\phi_{2}\right) / 2\right)$ は常に 一定となり，位相項である $\exp \left(\mathrm{i}\left(\phi_{1}+\phi_{2}\right) / 2\right)$ に従って $\mathrm{a} \sim \mathrm{d}$ の4状態を準備できる. 前段の干渉計で時間分離された2連 パルスに対して，a $\rightarrow \mathrm{a}$ の駆動条件により位相差 $0^{\circ}(\mathrm{X} 0)$, $\mathrm{a} \rightarrow \mathrm{c}$ で位相差 $180^{\circ}(\mathrm{X} 1), \mathrm{a} \rightarrow \mathrm{b}$ で位相差 $90^{\circ}(\mathrm{Y} 0), \mathrm{a} \rightarrow \mathrm{d}$ で位相差 $270^{\circ}(\mathrm{Y} 1)$ の 4 状態を生成できる。方式Bでは，Y 基底に対応する強度 $1 / 2$ ，位相差 $90^{\circ}$ の 2 状態と，Z基底に対 応する強度 0,102 状態が必要となる (Fig. 2左下). MZ変 調器片経路を $90^{\circ}$, 他方を $0^{\circ}$ と $180^{\circ}$ の変調位相で駆動する ことで, 強度 $1 / 2$, 位相差 $90^{\circ}$ の, f, 片経路を $0^{\circ}$ ，他方を 0 と $180^{\circ}$ で駆動することで，強度 $0 ， 19 \mathrm{~g}, \mathrm{~h}$ 準備でき る。 2 連パルスに対して, $\mathrm{e} \rightarrow \mathrm{f}$ の変調で位相差 $90^{\circ}(\mathrm{Y} 0)$,

(a)

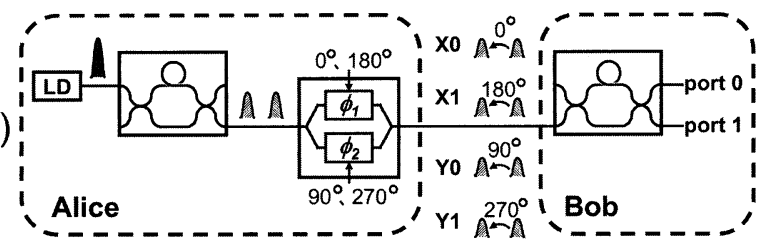

(b)

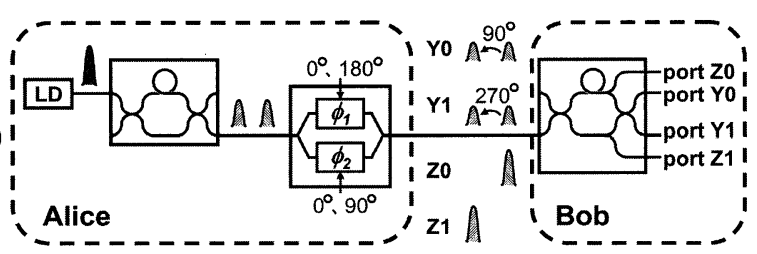

Fig. 1 Experimental setups for (a) phase coding and (b) phase-time coding. (a)
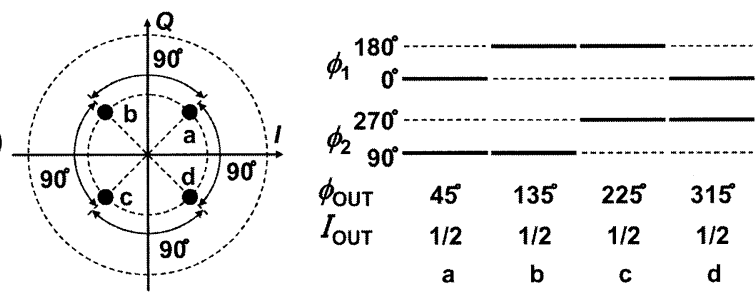

(b)
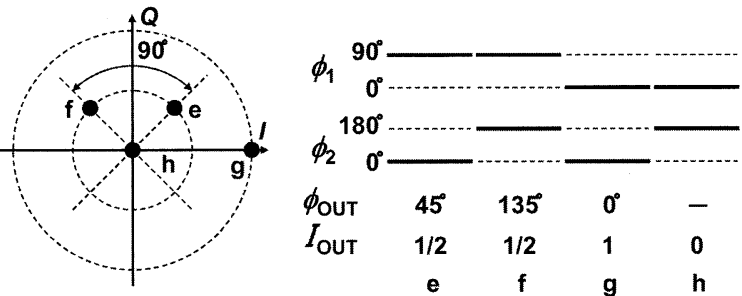

Fig. 2 Applied modulations for phase coding (a) and phasetime coding (b).

$\mathrm{f} \rightarrow \mathrm{e}$ で位相差 $270^{\circ}(\mathrm{Y} 1), \mathrm{g} \rightarrow \mathrm{h}$ で前パルス $(\mathrm{Z} 0), \mathrm{h} \rightarrow \mathrm{g}$ で後パルスのみ $(\mathrm{Z} 1)$ の状態を生成できる.

この量子暗号送信器の特性を調べる為に実証実験を 行った。 LDにより，1.6ns間隔， $100 \mathrm{ps}$ 幅の光パルスを生 成し，遅延差800 psのPLC MZ干渉計を使用して $800 \mathrm{ps}$ 間 隔の2連パルスへと時間分離した。この2連パルスに対し てFig. 2の変調を行い，受信側の $2 \times 2$ 干渉計及び $2 \times 4$ 干 渉計を通して干渉特性を測定した。 XとY基底の 2 連パル スの位相差が $90^{\circ}$ 異なっていること，及び， $\mathrm{Z}$ 基底で消光 した光パルスが十分消光されていることを確認する為, 送信側PLCの温度を変化させて出力 2 連パルス間の位相を 変えたときの, 受信側PLCの各ポートに出力される光パ ルス強度の変化を測定した．測定結果をFig. 3に示す．万

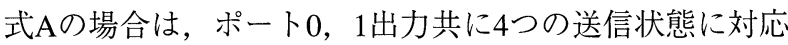
する光パルス強度が，位相 90 ずつずれた正弦波曲線を描 くことが確認できた。各正弦波のピーク高さの違いは， 変調器駆動信号の設定值からのずれにより強度項が等し くならなかったことによる. 方式Bの信号を受信側PLCの Y0，Y1ポートで観測すると，PLC温度に従ってY基底の 2パルスの光強度が変化する一方，Z基底の2パルスの光強 度はPLC温度によらず一定となることを確認できた。 Table 1に，各光パルスの消光比から計算される誤り率を まとめる．誤りは変調器駆動信号のずれや干渉計の精度
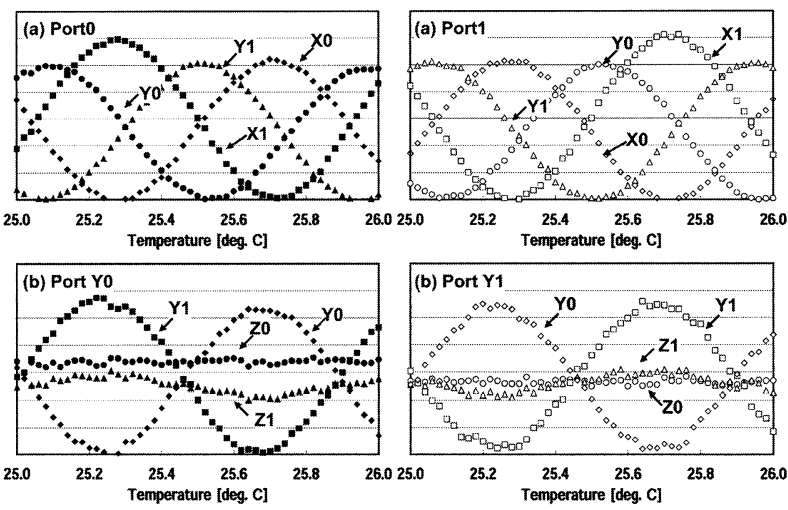

Fig. 3 Results for (a) phase coding and (b) phase-time coding. 
Table 1 Error rate calculated from pulse intensity.

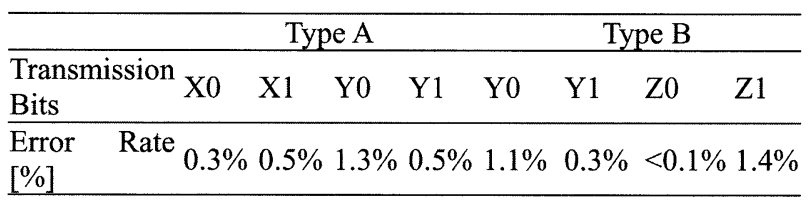

に起因しているが，平均して0.7\%以下の良好な誤り率を 得た。

\section{APD用の信号検出回路の開発とモジュール化}

\section{1 超小型APD モジュール}

単一光子検出には, InGaAs-APDを冷却し, ゲートモー ド動作を用いる14). 小型低消費電力のペルチェ素子で十 分な冷却を行うには，低温部への熱流入を最小限に抑え る必要がある. APD素子の信号入出力ボンディングワイ ヤが支配的な熱流路となる。高周波特性はワイヤの接続 数に依存するため, 断熱性と広帯域性の要求は相反す る. APDモジュールは, これらの要求に対して以下のよ うに最適化した設計を行った。

(1)2組のAPD素子を，1つのペルチェ素子に搭載する事で, モジュールの小型化と冷却効率の改善を両立した. 熱シ ミュレーションの結果, $-70{ }^{\circ} \mathrm{C}$ での冷却が期待された. (2) 2組のAPD素子とファイバを1つのレンズで光学結合し ファイバ取り出し方向を揃える事で, RF信号の伝送路設計 の自由度を確保した. (3)ゲートパルスの伝送路帯域(ゲー 卜帯域)の広带域化を実現するために, 終端用コプレナラ インを設置した.FDTD法によるシミュレーションの結 果, ボンディングワイヤ長が $5 \mathrm{~mm}$ 以下で $3 \mathrm{GHz}$ の帯域が期 待できた。試作したAPDモジュールをFig. 4に示す. モ ジュール本体のサイズは $23.3 \times 21.7 \times 15 \mathrm{~mm}^{3}$ である. 評価 の結果, $-73^{\circ} \mathrm{C}(200 \mathrm{~K})$ の冷却能力と, $1.02 \sim 1.05 \mathrm{~A} / \mathrm{W}$ の受 光感度, 測定限界以下のクロストーク特性, $3 \mathrm{GHz}$ のゲー 卜带域を確認した。このゲート帯域は, 従来例†1と比較し 15 倍の帯域であり，1 GHzのゲートパルスの繰り返しが可 能な帯域である。

\section{2 光子検出回路}

ゲートモードを用いたSPDでは，信号識別回路での チャージパルスを補償した識別回路が必要となる。従来 のチャージパルス補償回路15)では，APD素子の個体差や

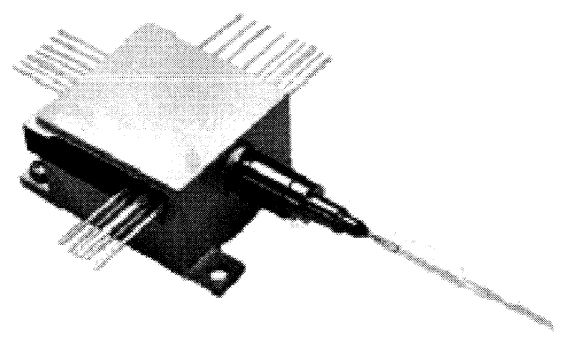

Fig. 4 APD Module.
実装のばらつきに対する高精度な調整が困難であった。 この問題を解決するために, Fig. 5に示すA/Dコンバータ (ADC) とデジタル信号処理による, セルフトレーニング 型識別回路を提案した ${ }^{16)}$.この信号処理回路をFPGAに よって実現し $1.5 \mathrm{GS} / \mathrm{s}$ のDCから出力される光子検出信号 の識別を行った.

\section{3 特性評価}

前記の超小型APDモジュールと組み合わせ，SPDの特性 評価を行った。まず，APDへ印加するゲートパルスの振 幅と, 識別しきい值の評価を行った。ゲートパルスと ダークカウント特性の関係をFig. 6に示す. 光子検出率一 定の条件では，ゲートパルス振幅が6 V以下では，ダーク カウント確率が急激に増加し, 量子鍵生成レートの劣化 につながる. 識別しきい值は, 識別回路で非光子検出状 態でのノイズ分布を解析し，ノイズ振幅の標準偏差の5倍 をしきい值とした。これはノイズを正規分布として， ダークカウント確率 $2.9 \times 10^{-7}$ に相当する. 以上の結果を用 いて測定したバイアス電圧に対する光子検出特性をFig. 7 に示す. ダークカウント確率 $P_{d}=2 \times 10^{-4}$ に於いて, 光子 検出効率 $\eta=30 \%$ あ゙り ${ }^{17)}$, 従来7) と比較して, 3倍の鍵 生成レートの高速化が可能となる。

\section{WDMクロック同期技術}

4.1 同期技術

実際に量子暗号技術を活用するためには, 長距離・高

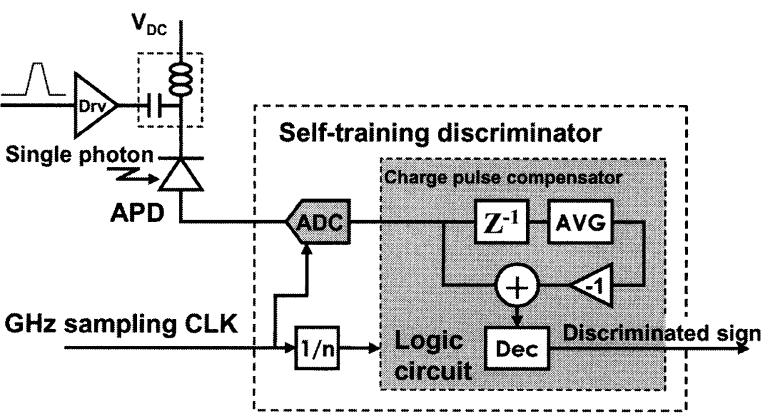

Fig. 5 Self-training discriminator circuit.

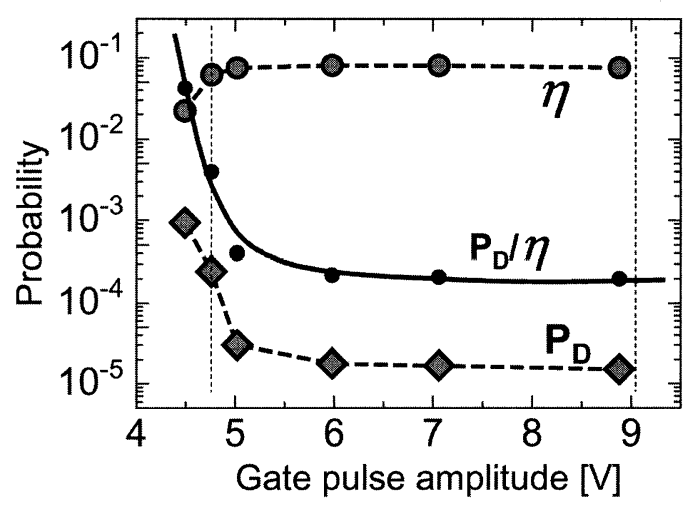

Fig. 6 Gate pulse amplitude vs. dark count characteristics.

${ }_{\dagger 1}$ PLI Inc., AGD-25-SE-1-B1. 


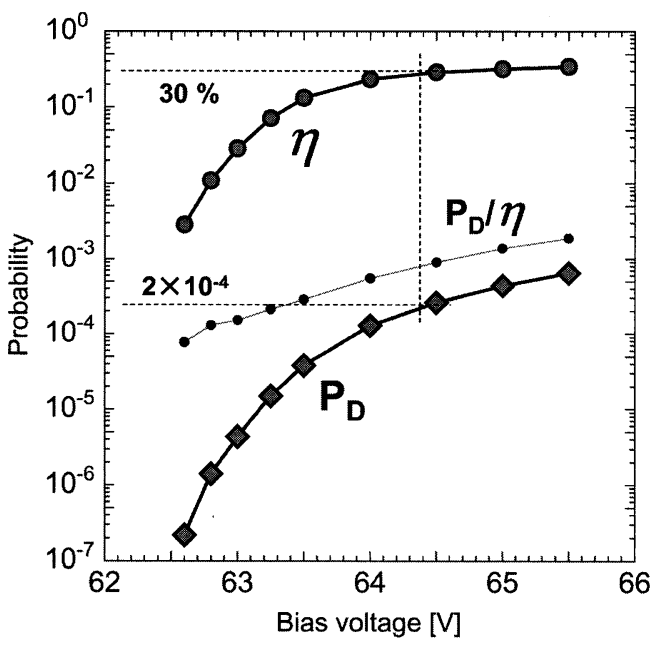

Fig. 7 Photon detection characteristics.

速条件においても安定した量子鍵配送を行わなければな らない，特に，長時間にわたって伝送路の遅延変動を補 償し，光子bit情報を正確に受信する同期技術は必要不可 欠な技術である。量子信号は単一光子伝送であるため， 光パワーが非常に小さく, 信号自体からはクロック抽出 できない。このため，単一光子伝送を補助する同期信号 を量子信号と同一伝送路に伝送する必要があるが，実現 する方式として大きくTDMとWDMの二つの方式がある. TDM方式は同期古典信号と量子信号を時間多重して伝送 する。ファイバ非線形性の影響を受けないという利点も あるが, 単一の受信器によって, 古典・量子両信号を受 信する場合, 受信器に $60 \mathrm{~dB}$ 以上のダイナミックレンジが 要求される. 古典, 量子信号それぞれを別の受信器に よって受信する場合, 高速 $(<\mathrm{ns})$ の光スイッチが必要と いう久点がある。一方，WDM方式は別波長の同期古典信 号と量子信号を多重して伝送する。受信器に大きなダイ ナミックレンジ不要, 高速光スイッチ不要という利点が
あるが，非線形ノイズを抑圧することが必要になる。ダ イナミックレンジや高速かつ低損失の光スイッチの実現 性を考えるとWDM方式が有力である，以下では，WDM 方式の実現手法について説明する.

\subsection{WDM同期技術}

WDM方式では, 同期信号から量子信号への自然ラマン 散乱クロストークにより量子信号のSN比が劣化して，鍵 生成性能が低下するという問題があった18). そこで，(1)量 子信号の受信干渉計の前に狭帯域光フィルタを挿入し伝送 中に漏れ込んだクロストークを抑圧，(2) 同期信号の出力パ ワーを受信可能な最低レベルに設定し出力時のクロストー クを低減, (3)受信側で同期信号に光Pre-Ampを挿入して出 カパワーをさらに低減，といった光フィルタリングとパ ワー制御を行い，クロストークの影響を最小限に抑える。

\section{3 実 験}

上記技術を適用し，1方向PLC干渉計およびWDM同期を 用いてFig. 8の構成によりフィールド実験を行った ${ }^{19)}$ 。こ こでは光子検出器として SSPD ${ }^{5)}$ を用いた，比較のため同 期信号を別芯ファイバで送った場合の特性も測定した。 伝送距離 $65 \mathrm{~km}$ と $97 \mathrm{~km}$ における量子鍵生成の結果をFig. 9 に示す. Fig. 9(a)より, 平均光子数 $\mu$ を変化させても, 同 期信号をWDM伝送した場合と別芯で送信した場合とで結 果がほぼ一致していることが見て取れる。これよりクロス トークが十分抑圧できていることが確認できた。 BB84を 実装した装置ではこれまでより10倍高速なクロック周波数 $625 \mathrm{MHz}$ 用いることにより，平均光子数 $0.4 て ゙ ~ 97 \mathrm{~km}$ ファ

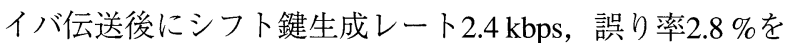
得た。平均光子数 $0,0.15,0.4$ における光子検出率と誤り 率から，デコイ法を適用した場合に安全性が保証できる 鍵のレート 20) は漸近的に0.78-0.82 kbpsであると見積もられ た。デコイ法による鍵生成を行うには，平均光子数をパ

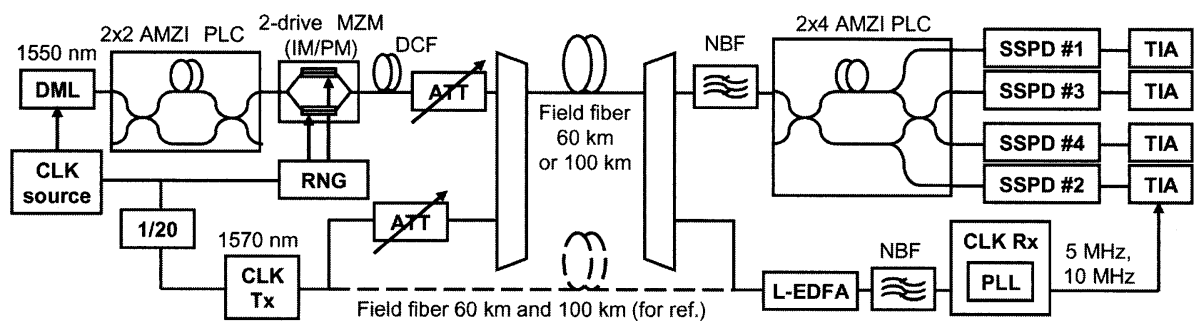

Fig. 8 Experimental setup.

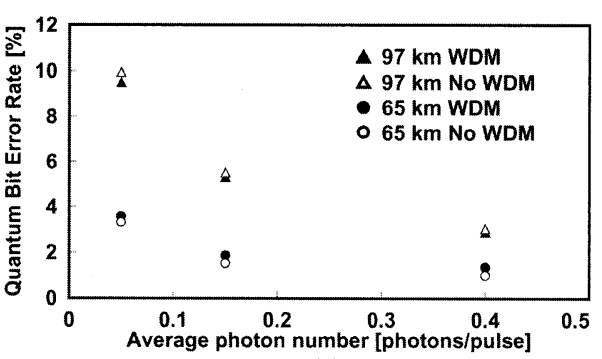

(a)

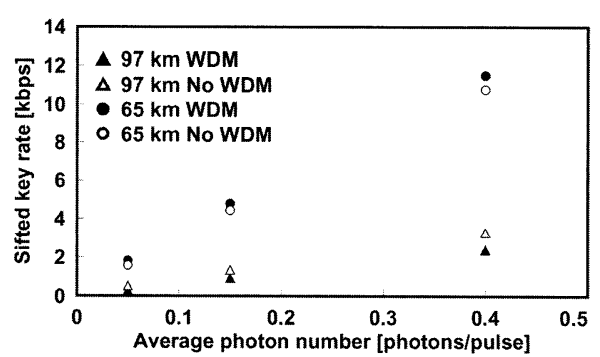

(b)

Fig. 9 Quantum key generation performance vs. mean photon number (a)QBER (b)Key generation rate. 
ルスごとにランダムに選び，符号の有限長を考慮した漏 洩情報量推定を行う必要がある21).

$$
\text { 5. まとめ }
$$

以上，量子暗号の高速化に不可欠な (i) PLC (Planar Lightwave Circuit)を用いた干渉計，(ii) APD用の信号検出 回路の開発とモジュール化，(iii) WDMクロック同期技術 について説明した。ささに，初期的なシステムにおいて 伝送距離 $97 \mathrm{~km}$ でシフト鍵生成レート $2.4 \mathrm{kbps}$ 得た。これ は伝送距離 $50 \mathrm{~km}$ において約 $25 \mathrm{kbps}$ に相当する.クロック 周波数を $1.25 \mathrm{GHz}$ にあげ，SSPDより高感度のAPD光子検 出器を利用することでシフト鍵生成レート $1 \mathrm{Mbps}$ (安全鍵 レート $100 \mathrm{kbps}$ 以上)にも達するものと思われる. 今後シ ステムとしての完成度を高めることにより，メトロ圈内 で実用的な性能を持つ量子暗号ネットワークが実用化さ れていくことが期待される.

\section{謝 辞}

本研究の一部は, 情報通信研究機構(NICT)「量子暗号技 術の実用化のための研究開発」の成果である.

\section{参考文献}

1) N. Gisin, G. Ribordy, W. Tittel, and H. Zbinden: Rev. Mod. Phys. 74 (2002) 145

2) 富田 章久：オプトロニクス 26（2007）147。
3）富田 章久：電子情報通信学会論文誌 A J90-A (2007) 358 .

4) K. Inoue, E. Waks, and Y. Yamamoto: Phys. Rev. A 68 (2003) 022317.

5) S. Miki, M. Fujiwara, M. Sasaki, and Z. Wang: IEEE Trans. Appl. Supercond. 17 (2007) 285.

6) N. Namekata, S. Sasamori, and S. Inoue: Opt. Express 14 (2006) 10043.

7) Z. L. Yuan, B. E. Kardynal, A. W. Sharpe, and A. J. Shields: Appl. Phys. Lett. 91 (2007) 041114.

8) J. C. Bienfang, A. J. Gross, A. Mink, B. J. Hershman, A. Nakassis, X. Tang, R. Lu, D. H. Su, C. W. Clark, C. J. Williams, E. W. Hagley, and J. Wen: Opt. Express 12 (2004) 2011.

9) T. Honjo, H. Takesue, H. Kamada, Y. Nishida, O. Tadanaga, M. Asobe, and K. Inoue: Opt. Express 15 (2007) 13957.

10) H. Takesue, S.-W. Nam, Q. Zhang, R. H. Hadfield, T. Honjo, K. Tamaki, and Y. Yamamoto: Nature Photonics 1 (2007) 343.

11) A. Muller, T. Herzog, B. Huttner, W. Tittel, H. Zbinden, and N. Gisin: Appl. Phys. Lett. 70 (1997) 793.

12) Y. Nambu, K. Yoshino, and A. Tomita: J. Mod. Optics (in press).

13) K. Yoshino, A. Tanaka, Y. Nambu, A. Tajima, and A. Tomita: Technical Digest of ECOC2007, 2007 (IEEE, Berlin, 2007) paper 9.4.7.

14) G. Ribordy, J.-D. G autier, H. Zbinden, and N. Gisin: Appl. Opt. 37 (1998) 2272

15）たとえばD. S. Bethune, W. P. Risk, and G. W. Pabst: J. Mod. Optics 51 (2004) 1359.

16）高橋成五, 田島 章雄, 富田 章久：電子情報通信学会2007総 合全国大会 (2007) CS-7-4.

17）高橋 成五, 江口 明大，浜本 貴一，田島 章雄, 富田 章久： 第55回応用物理学会学術講演会 (2008) $27 \mathrm{pZE}-8$.

18）前田和佳子, 田中 聡寛, 田島 章雄, 高橋成五：電子情報通 信学会 光通信システム研究会 (2005) OCS2005-14.

19) A. Tanaka, M. Fujiwara, S. W. Nam, Y. Nambu, S. Takahashi, W. Maeda, K. Yoshino, S. Miki, B.Baek, W. Zhen, A. Tajima, A. Tomita, and M. Sasaki: Technical Digest of OFC, 2008 (OSA, San Diego, 2008) paper OWJ2.

20) M. Hayashi: New J. Phys. 9 (2007) 284

21) J. Hasegawa, M. Hayashi, T. Hiroshima, A. Tanaka, and A. Tomita: e-print arXiv: 0705.3081v1. 